
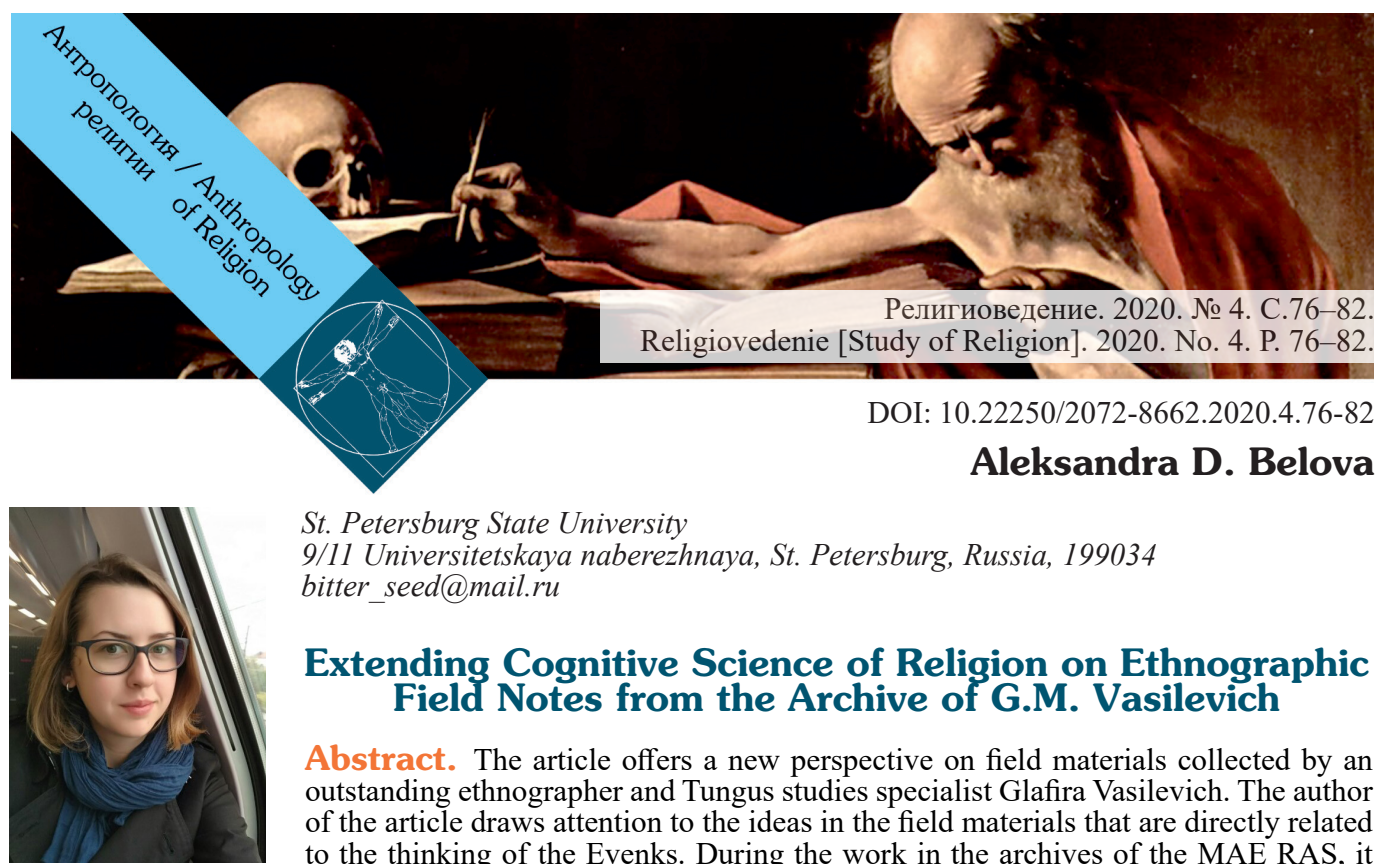

St. Petersburg State University

9/11 Universitetskaya naberezhnaya, St. Petersburg, Russia, 199034

bittersseed@mail.ru

\title{
Extending Cognitive Science of Religion on Ethnographic Field Notes from the Archive of G.M. Vasilevich
}

Abstract. The article offers a new perspective on field materials collected by an outstanding ethnographer and Tungus studies specialist Glafira Vasilevich. The author of the article draws attention to the ideas in the field materials that are directly related to the thinking of the Evenks. During the work in the archives of the MAE RAS, it was noted that field materials relating to the Evenki imagination can be analyzed via cognitive anthropology and psychology. The article takes a variety of materials for analysis that refers to the thinking of the Evenks: hunting amulets, names, ideas of the appearance of birds and the image of fire. Ideas on implicit meanings (Douglas), the theory of mind (Gervais and others) and promiscuous teleology (Banerjee, Bloom and others) are taken as the methodological basis for the analytical commentary. Each of the selected concepts and all of them together allow to look at the imagination of the Evenks, which generates ideas about the supernatural based on everyday thinking. The article shows how linguistic, logical and moral categories are extended to the animal and natural world through misattribution.

Key words: theory of mind, promiscuous teleology, cognitive religious studies, field notes, anthropology, Evenks, Vasilevich

\section{Бепова А.Д.}

Санкт-Петербургский государственный университет 199034, Россия, Санкт-Петербург, Университетская набережная, 9/11 bitter_seed@mail.ru

\section{Переоткрывая мифопогическое воображение эвенков: когнитивное измерение попевых заметок Г.М. Василевич}

Аннотация. В настоящей статье предлагается новый взгляд на полевые материалы, собранные выдающимся этнографом-тунгусоведом Глафирой Макарьевной Василевич. Автор статьи обращает внимание на те идеи в полевых материалах, которые непосредственно связаны с мышлением эвенков. В процессе работы в архиве МАЭ РАН было отмечено, что полевые материалы, касающиеся воображения эвенков, могут быть подкреплены современной когнитивной наукой. В качестве материалов для анализа выступают разнородные материалы, отсылающие к мышлению эвенков: охотничьи амулеты, названия, представления о внешнем виде птиц и об образе огня. В качестве методологической базы аналитического комментария взяты идеи об имплицитных значениях (М. Дуглас), теории разума (Жерве и другие), а также беспорядочной телеологии (Банержи, Блум и другие). Каждый из выбранных концептов и все они вместе позволяют взглянуть на воображение эвенков, генерирующее представления о сверхъестественном на основе повседневного мышления. В статье показано, как языковые, логические и моральные категории через мисаттрибуцию расширяются до мира животных и природных явлений.

Кпючевые спова: теория намерений, когнитивное религиоведение, беспорядочная телеология, полевые материалы, антропология, эвенки, Василевич 


\section{Антропология религии / Anthropology of Religion}

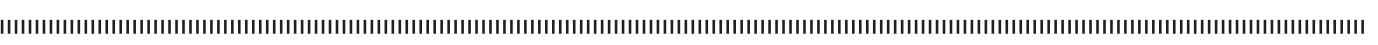

Vasilevich Glafira Makaryevna (1895-1971) is a Russian linguist and ethnographer. She was one the first students of Vladimir Bogoraz and Leo Sternberg sent to study expedition trips to Pechora (1923) and Vyatka region (1924). After graduating from the Faculty of Ethnography of the Geographical Institute in 1925, she was sent on a field trip from the Leningrad branch of the Committee of the North to work with the Evenks and collect ethnographic and linguistic materials. In total, she took part in 11 expeditions, where she studied the language, folklore, social life and shamanism of Evenks.

She collaborated with the Museum of Anthropology and Ethnography, where in 1930 at the exhibition on the history of religion she prepared a section "Soul after death". In 1946, her archive started to be formed in that museum. The archive contains extensive ethnographic materials, articles and manuscripts by Glafira Vasilevich, and researchers worked with them after her death. G. Vasilevich was the author of a large number of articles in Russian and Evenk languages.

Editing is a natural process in working with field materials, and it was the case for the ethnography of the time. The researchers point out that by the time of the redaction of an article the materials could be significantly changed. In particular, comparison of the text of a publication with the "Report on a business trip to the Tungus of Turukhansk region in June-September 1930" [Klitsenko, 2011] leads to the assumption that the initial field records of 1930 concerning the number and composition of wooden sculptures of the shaman Chum/tent (ducan) for Iconipko fest, in the article of 1957 [Vasilevich, 1957] were supplemented and even modified.

This observation raises an interesting, on our part, problem of handling field material. On the one hand, the author could travel to other field trips and supplement the information collected for the first time. On the other hand, these changes in the text of the article compared to the field notes may indicate regional differences between different Evenk groups. In any case, we believe that field notes deserve as much attention from external researchers as published materials, especially if they are accessible.

The materials collected by $G$. Vasilevich provide interesting information about the subjects of Evenk mythology. In addition, it is a vivid illustration of syncretic thinking which was circulating among these peoples. Not being the specialists in Evenk mythology and culture, we want to refer to her field materials in this sense. Indeed, as will be shown below, the materials have a certain potential to serve as illustrative material for modern cognitive concepts.

Glafira Vasilevich has a huge scientific legacy, both in printed works and field materials. However, due to the fact that she herself was actively working with her field notes, it led to a lack of attention to them from other researchers. Indeed, who else but a collector can best handle the gathered information? But scientific paradigms are changing, and ethnography and anthropology today are significantly different than those 70-90 years ago. The heritage review can always say something more about "raw" field material. This is the purpose of this article.

\section{Methodology}

We've decided to limit ourselves to the earliest field notes, those of the $1920 \mathrm{~s}-$ 1930s [SA MAE RAS. F. 22. I. 2. F. 4, 10], and look at them as a source of collective imaginary. In order to do this, we will turn to those methodological traditions that derive religion and mythology from ordinary thinking.

Long before cognitive religious studies, Mary Douglas referred to the connection between the mind and religion. In the foreword to her essays collection «Implicit meanings», she notes that attention must be paid to implicit phenomena to understand explicit actions and beliefs [Douglas, 1999, viii]. She assumes that there is some preconceived intuition, hidden and inaccessible, but it consctructs the basis of all other knowledge [Ibid., 203]. The animal classifications, in particular, are based on the idea of this biased intuition, which Douglas described. Notes about the animal world of the Evenks, collected by Vasilevich, allow us to draw parallels with Douglas materials.

Another important concept, which is more modern and relates to cognitive religious studies, is the theory of mind. Originally an ability to attribute mental states and subjectivity to other people, in religious studies it has expanded to a cognitive mechanism that ascribed agency to non-human beings [Gervais, 2013]. This ability is considered 


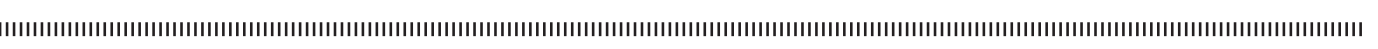

fundamental to the development of social relations. In addition, this ability can explain a belief in the supernatural, when the properties of an agent are attributed to random natural phenomena, what Luce Galen calls misattribution or over-attribution [Galen, 2017]. We will be able to see a similar mechanism in Evenk materials.

Finally, a concept inextricably linked with the theory of mind to which we will turn to is the promiscuous teleology. Experimental psychologists [Kelemen \& Rosset, 2009] have shown that we tend not only to attribute human qualities to superhuman agents, but also to attribute purpose and meaning to generally random events. In particular, researchers show that people tend to relate some teleological beliefs about nature to life events [Banerjee \& Bloom, 2014]. We turn to this concept of promiscious teleology to understand Evenki beliefs about superstition and destiny.

These three ideas - that there is some preconceived intuition about the world around us, that the notion of an agent extends to the entities that are not agents, and that promiscuous teleology affects the interpretation of certain natural events - will help us to better understand the meaning of certain ethnographic sources of G. Vasilevich.

\section{Materials}

The principal part of the analysis materials was taken from early field notes of Glafira Vasilevich [SA MAE RAS. F. 22. I. 2. F. 4, 10]. In addition, some data is taken from certain files from the same fund [SA MAE RAS. F. 22. I. 2. F. 37]. The object includes materials from which one can learn about the work of the Evenk imagination and some of their a priori ideas. When working with the field notes, we noticed that the materials recorded by Vasilevich can be analyzed in terms of cognitive religious studies.

Cognitive anthropology explores the cognitive processes and features of the epistemology of people, and we think this article could be inscribed in this paradigm. The materials analysed here are not always directly related to religious practice. However it may serve the evidences of beliefs based on the reasoning about or reflection of the outside world. To be precise, we are trying to answer the question: what can Vasilevich' field materials add to the understanding of spiritual culture of the Evenks, in particular to the mental dimension of this culture? In other words, the notes will serve as a source of information about the thinking of the Evenks.

For the reasons of convenience, we divide our findings into three sections. The first one, material objects: mascots and elements of cult practice, the production of which involves associative thinking. The second section focuses on the reasoning about the appearence of the different types of birds. Finally, the third section will be dedicated mainly to fire as an actor of destiny and animate being. The ideas of the theory of mind, promiscuous teleology as well as implicit meanings will be used to analyse fieldnotes of all types.

\section{Material objects and their functions}

Glafira Vasilevich initially had focused on hunting amulets to make a detailed ethnography of a hunting rite. Amulets are an obligatory component of hunting and hunting rituals. Talismans in Evenk culture are represented in various forms. For example, you should take a wooden figure of a man to be lucky when you hunt, or a dried fish so that get luck while fishing [SA MAE RAS. F. 22. I. 2. F. 4, fol. 24]. Already here it is noticeable how thinking by analogy is incorporated, there is some implicit knowledge.

However, even more prominent is the observation of those amulets that represent the body parts of wild animals. For example, the Evenks dry up and carry the heart of a wild deer with them for a successful hunting as well. For the same reasons the hunters carried jaws and nose of sable [SA MAE RAS. F. 22. I. 2. F. 4, fol. 178]. The heart in this case serves as a place of concentration of vital force. The jaws and nose are those parts of the animal that are less developed in humans. We can say that implicit promiscuous teleology works here, when a person believes that for a successful hunt he needs to assign some qualities of an animal.

$\mathrm{G}$. Vasilevich also describes another nontrivial case, the ritual of healing. There are no surprises that the ritual of healing in Siberian shamanism is often presented as playing out the extraction of the disease (in the form of a needle or pebble). The author in turn gives a description of the ceremony with the material symbol of the soul: «Sometimes all the people who are present are calling for the soul of the patient; and at the same time 


\section{Антропология религии / Anthropology of Religion}



the shaman pours water from a small cup onto paper in an empty cup. A bubble of water which appears represents the soul. Then the shaman takes the paper with a bubble, says something to it and puts it in the hat which he puts on the patient» [SA MAE RAS. F. 22. I. 1. F. 7]. Thus, there is an implicit knowledge that the soul in the form of a bubble will return to the patient. The cure does not occur through the removal of the disease, but through the materialization of the soul, which is given back to the sick patient.

Such causal relationships are one of the manifestations of folk-psychology or epistemology. Since Vasilevich was also a linguist, she revealed some correspondences of the names of toponyms and their literal translation. Evenki from the region Podkamennaya Tunguska call the sky kalan which means literally a cauldron [SA MAE RAS. F. 22. I. 2. F. 37, fol. 4]. That follows from the notion that the sky is tilted to the ground, like a cauldron.

What is in heaven is also called in accordance with terms from ordinary language. The polar star is the hole, the entrance to the upper world, is called the «sky hole» [Ibid.]. Milky Way is a «ski trail».

The analogies in hunting language are also noticeable: a blunt arrow for a squirrel hunting is still called $u l u k i$, the same word to name a squirrel. We dwell on these linguistic examples in order to show how the hunter's consciousness takes the names of familiar reality to more general ones, and makes them achievable and predictable. So, everyday thinking and language serve as the basis for thinking about the world around, built by analogy with what is already known.

\section{The agency of birds}

In this subsection, we would like to consider an "unexpected" agency: how the properties of thinking and consciousness are attributed to those who do not possess it. By unexpected agency, we understand the endowment of various natural phenomena and animals with the properties of human consciousness or human behavior, i.e. theory of mind [Gervais 2013]. The attribution is a common place in native Siberian peoples. However, in the case of the interpretation of the appearance of the animals that surround the Evenks, we see the emergence of some moral categories.

According to Evenk narratives, the Good Source marked with some special signs the animals that helped or obstructed the process of building the world. G. Vasilevich herself noted that the Evenks did not have the idea of retribution: more likely the good / evil dualism was brought with Christianity [SA MAE RAS. F. 22. I. 2. F. 37, fol. 26]. However, at the beginning of the 20th century it seems to be the local explanatory models of full value. So, interpretation of the explanatory models can be a reach material for socalled folk-epistemology. We would like to consider in more detail one plot, the world of animals and birds.

As per Evenk beliefs, many animals owe their appearance to certain circumstances, which are reflected in folklore. Particularly interesting examples can be found in the bird world. So, common goldeneye ( $g o g o l$, hereinafter the names of birds are replicated in Russian) has a white mark on his head. This is a sign of a kiss from the Good Source for the extraction of soil from the bottom of the sea, that according to the cosmological ideas led to the creation of land. Loon (gagara) has cracked legs for not fulfilling orders of the Good Source. This bird almost can't walk, only swim and fly. In the case of these two birds, we can see that they got their look from the different attitude of the Good Source. On the one hand, benevolent treatment and remuneration, on the other hand, punishment.

In addition to retribution, there are other typically human reactions in the Evenk world of birds. For example, the wood grouse (glukhar') has red eyes because of tears. He cried because the Good Source sent him to live in a cold land. But on the sides, he has white swan feathers, which the last gave him to survive there [SA MAE RAS. F. 22. I. 2. F. 4, fol. 59-71]. Here one can see very clearly that birds are full-blown carriers of agency, rather than simply experiencing the whims of Good Source.

There are other similar examples from the bird world, where they owe their appearance to the interaction between themselves and other species. Thus, a rounding on the tail of the black grouse (teterev) from the fact that the grouse (glukhar') grabbed him. Pazel grouse (ryabchick) is small, because he scared a Good Source, and the last dropped the first figure of a human [Ibid.]. Here again, the category of revenge can be seen. 


\section{Антропология религии / Anthropology of Religion}

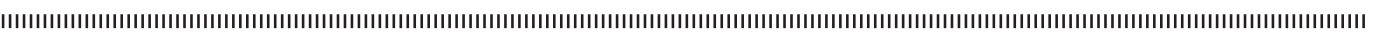

Finally, there are relatively neutral examples. The red crossbill ( $k l^{\prime}$ 'ost) has the curved beak because one of them has untied the knot with its beak, with which a bear tied a girl to a tree. Or, the biggest bird, the mountain eagle, is the owner of all birds [Ibid., fol. 93].

As Mary Douglas notes concerning her own field materials, "A deviation from characteristically animal behavior shows them to be not entirely animal, but partly human» [Douglas, 1999, 49]. Full participants in the creation of the world, birds in the Evenk world are the obvious bearers of consciousness.

All these interpretations are somehow connected with the notion that animals are carriers of human consciousness, and also build relationships with each other in the same way as humans. In the case of the interpretation of the appearance of the animals that surround the Evenks, we see the emergence of some moral categories. In this way, the Evenks project their consciousness and agency onto the world around them, the world of birds and animals, which makes it possible to see a manifestation of theory of mind in their legends.

\section{Fire and it's power}

The theory of mind and especially promiscuous teleology could not only be found in the animal world. The last plot, but not least, which we would like to consider, is an image of fire. We call it an «image», but at the same time we assume not a symbolic, but a real interaction with fire, that is, again, forms part of folk epistemology.

As Glafira Vasilevich notes, the fire was of tremendous importance in the life of stray hunters, which resulted in the development of a whole series of prohibitions regarding the treatment of fire of the hearth. She herself remarks that «the fire is like something alive, human alike» [SA MAE RAS. F. 22. I. 2. F. 37, fol. 76-77]. The fire master (called musun or itchin, depending on the Evenk group) is usually a grandmother. Fire that plays an important role in a daily life of Evenks will stop burning if one disobeys the following restrictions:

Do not throw sharp objects near the hearth, because you can gouge out grandmother's eyes or hurt her legs. You cannot spit into the fire, you can get into the grandmother's face; besides, the tongue can get sick. This example involuntarily reminds us of a classic story described by Frazer about the sympathetic bond between milk and cows that is retained for some time [cf. Frazer, 1988]. The danger of spitting suggests a similar sympathetic connection between the saliva and the one who gives it away.

Like the examples of birds, fire is not a passive recipient, but also responds to insults. You cannot throw inside dirty rags because the grandmother will get angry. In turn, her favour can be obtained by fertilizing her with a piece of fat.

Communication with fire is also important. A crackling sound can change intentions, for example, Vasilevich cites a case when a crackling sound from the hearth forced her interlocutor to change his mind and not to go hunting [SA MAE RAS. F. 22. I. 2. F. 37, fol. 76-77]. The connection between a natural phenomenon and an event from human life is particularly evident here. Cognitive researchers would call this an over-attribution of agency [Galen, 2017]. Konika Banerjee and Paul Bloom notice that «The perception of purpose in nature and in life events are not unrelated psychological phenomena, but rather, that they share a common cognitive source: a domain-general orientation to purpose and intention» [Banerjee \& Bloom, 2014].

In earlier trips (1925-1927), the local guides of G. Vasilevich who did not leave the taiga farther than the nearest Russian village used to talk to the trees and the rivers like living people, as well as to the fire. Thus, what is commonly considered syncretic thinking can be split into the idea of total agency (theory of mind) and promiscuous teleology.

\section{Conclusion}

One of the goals of ethnography of that time was to control education among small nations, to remove them from a primitive state. However, G. Vasilevich underlines the power of ideas of primary socialization, the school still did not work by 1934 . She writes: «If shamanism disappears, the representations and minor actions are preserved for a long time» [SA MAE RAS. F. 22. I. 2. F. 37, fol. 4]. These ideas and small actions are inseparable from the everyday life of the Evenks. At the same time, they show the deep rootedness of beliefs in the reflection on the surrounding material world.

G. Vasilevich managed to successfully record details and representations concerning the everyday life of the Evenks, which are not directly related to religion. Having 


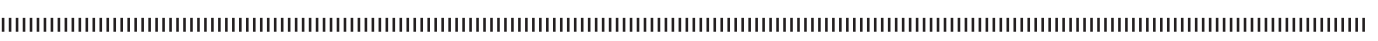

caught and described these little notions and actions, it was as if she had anticipated Mary Douglas' reflection on implicit meanings. In this article we tried to show how interesting the materials collected by Vasilevich are for modern humanities.

Armed with modern concepts such as theory of mind and promiscuous teleology, we tried to see implicit world of Evenks. Thinking by analogy is widely represented in their language, as well as in the use of talismans, through which they influencethe world and try to influence fate. The most obvious and interesting illustration of the Evenk imagination is that of their bird world, where we could discover completely human scenarios of interaction. Finally, the idea of grandma fire, who has some real power, shows the Evenks' everyday life as profoundly theistic and teleological.

This article offers an attempt at dialogue between historical folklore materials and a new methodology for cognitive research on religion. However, it also invites the reader to see once again the wealth and variety of field materials collected by the outstanding scholar of her time Glafira Vasilevich.

\section{Благодарность}

10083

Исследование поддержано грантом Российского научного фонда № 16-18-

\section{Acknowledgement} $18-10083$

The research is supported by the grant of the Russian Science Foundation № 16-

\section{Бибпиографический список}

1. Клиценко, Ю. Традиции праздника Иконипко в полевых материалах Г.М. Василевич и Н.П. Никульшина [Электронный ресурс] / Ю. Клиценко // Оксикатан, Информационнообразовательный ресурс Эвенкии. - URL: http://osiktakan.ru/ethnos1/ikonipko_vasilevichnikulshin.html (дата обращения 17.05.2019).

2 . Василевич, Г.М. Древние охотничьи и оленеводческие обряды эвенков / Г.М. Василевич // Сборник музея антропологии и этнографии. - 1957. - Т. 17. - С. 151-185.

3. Научный Архив Музея Антропологии и Этнографии Российской Академии Наук (НА МАЭ РАН). Ф. 22. ОП. 2. Д. 4.

4. Научный Архив Музея Антропологии и Этнографии Российской Академии Наук (НА МАЭ РАН). Ф. 22. Оп. 2. Д. 10.

5. Научный Архив Музея Антропологии и Этнографии Российской Академии Наук (НА МАЭ РАН). Ф. 22. ОП. 2. Д. 37.

6. Научный Архив Музея Антропологии и Этнографии Российской Академии Наук (НА МАЭ РАН). Ф. 22. ОП. 1. Д. 7.

7. Banerjee, K., Bloom, P. Why did this happen to me? Religious believers' and non-believers' teleological reasoning about life events / K. Banerjee, P. Bloom // Cognition. - 2014. - Vol. 133. P. 277-303.

8. Douglas, M. Implicit Meanings: Selected Essays in Anthropology (2nd edition) / M. Douglas. London: Routledge, 1999. - 324 p.

9. Frazer, J. Folklore in the Old Testament: Studies in Comparative Religion, Legend, and Law /

J. Frazer. - Random House Value Publishing, 1988. - 476 p.

10. Galen, L. Overlapping Mental Magisteria: Implications of Experimental Psychology for a Theory of Religious Belief as Misattribution / L. Galen // Method \& Theory in the Study of Religion. - 2017. - Vol. 29. - № 3. - P. 221-267.

11. Gervais, W.M. Perceiving Minds and Gods: How Mind Perception Enables, Constrains, and Is Triggered by Belief in Gods / W.M. Gervais // Perspectives on psychological science: a journal of the Association for Psychological Science. - 2013. - № 8(4). - P. 380-394.

12. Kelemen, D. The Human Function Compunction: Teleological explanation in adults / D. Kelemen, E. Rosset // Cognition. - 2009. - Vol. 111. - № 1. - P. 138-143. 


\section{Антропология религии / Anthropology of Religion}

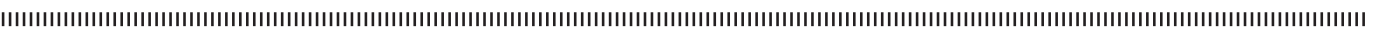

\section{References}

1. Klicenko Yu. Tradicii prazdnika Ikonipko v polevyh materialah G.M. Vasilevich i N.P. Nikul'shina [Traditions of the Ikonipko holiday in the field materials of G.M. Vasilevich and N.P. Nikulshina]. Available at: http://osiktakan.ru/ethnos1/ikonipko_vasilevich-nikulshin.html (accessed on May 17, 2019) (in Russian).

2. Vasilevitch G.M. Sb. Muzeya antropologii i etnografii [Collection of the Museum of Anthropology and Ethnography]. 1957, vol. 17, pp. 151-185 (in Russian).

3. Vasilevitch G.M. Nauchnyj arhiv muzeya antroplogii i etnografii rossijskoj akademii nauk [Scientific Archive of Museum of Anthropology and Ethography of Russian Academy of Science, SA MAE RAS]. Fund 22. Inventory 2. File 4 (in Russian).

4. Vasilevitch G.M. Nauchnyj arhiv muzeya antroplogii i etnografii rossijskoj akademii nauk [Scientific Archive of Museum of Anthropology and Ethography of Russian Academy of Science, SA MAE RAS]. Fund 22. Inventory 2. File 10 (in Russian).

5. Vasilevitch G.M. Nauchnyj arhiv muzeya antroplogii i etnografii rossijskoj akademii nauk [Scientific Archive of Museum of Anthropology and Ethography of Russian Academy of Science, SA MAE RAS]. Fund 22. Inventory 2. File 37 (in Russian).

6. Vasilevitch G.M. Nauchnyj arhiv muzeya antroplogii i etnografii rossijskoj akademii nauk [Scientific Archive of Museum of Anthropology and Ethography of Russian Academy of Science, SA MAE RAS]. Fund 22. Inventory 1. File 7 (in Russian).

7. Banerjee K., Bloom P. Why did this happen to me? Religious believers' and non-believers' teleological reasoning about life events. Cognition. 2014, vol. 133, pp. 277-303.

8. Douglas M. Implicit Meanings: Selected Essays in Anthropology (2nd edition). London: Routledge, 1999, 324 p.

9. Frazer J. Folklore in the Old Testament: Studies in Comparative Religion, Legend, and Law. Random House Value Publishing, 1988, 476 p.

10. Galen L. Overlapping Mental Magisteria: Implications of Experimental Psychology for a Theory of Religious Belief as Misattribution. Method \& Theory in the Study of Religion. 2017, vol. 29, no. 3, pp. 221-267.

11. Gervais W.M. Perceiving Minds and Gods: How Mind Perception Enables, Constrains, and Is Triggered by Belief in Gods. Perspectives on psychological science: a journal of the Association for Psychological Science. 2013, no. 8(4), pp. 380-394.

12. Kelemen D., Rosset E. The Human Function Compunction: Teleological explanation in adults. Cognition. 2009, vol. 111, no. 1, pp. 138-143.

Submitted for publication: April 27, 2020 Accepted for publication: August 10, 2020

Published: December 24, 2020 